\title{
CITIZENS ASSOCIATION OF GEORGETOWN $V$. WASHINGTON: AWARDING ATTORNEYS' FEES IN CITIZEN SUITS TO ENFORCE THE CLEAN AIR ACT
}

Traditionally American courts require that each litigant bear his own attorneys' fees. ${ }^{1}$ The "American rule," however, has not been without its exceptions: fee shifting may be authorized by statute $^{2}$ or under established equitable doctrines. ${ }^{3}$ Brief judicial recognition was accorded to an equitable exception allowing award of fees to a "private attorney general." 4 The Supreme Court in Alyeska Pipeline Service Co. v. Wilderness Society, ${ }^{5}$ however, abrogated further use of the private attorney general rationale in the absence of statutory fee shifting authority. ${ }^{6}$

Citizens Association of Georgetown $v$. Washington ${ }^{7}$ raises the issue of fee shifting in the context of enforcing the Clean Air Act. ${ }^{8}$ Ostensibly pursuant to the citizen suit provision of the Clean Air Amendments of $1970,{ }^{9}$ the United States District Court for the District of Columbia awarded attorneys' fees to the environmental interest groups who were the unsuccessful plaintiffs in the action. The fee award was made against officials of the District of Columbia who were joined as defendants in the suit on the allegation that they had failed their duty under the Act to regulate polluters. The district court found that the suit

${ }^{1}$ F.D. Rich Co. v. Industrial Lumber Co., 417 U.S. 116, 126 (1974); Fleischmann Distilling Corp. v. Maier Brewing Co., 386 U.S. 714, 717 (1967); Arcambel v. Wiseman, 3 U.S. ( 3 Dall.) 306 (1796).

${ }^{2}$ See notes 84-87 infra \& accompanying text.

${ }^{3}$ See notes 88-91 infra \& accompanying text.

4 See notes 105-06 infra \& accompanying text. Judge Jerome Frank first coined the phrase "private attorney general" in a 1943 case involving a private citizen's standing to sue a public official for violation of a specific statutory duty. See Associated Indus., Inc. v. Ickes, 134 F.2d 694, 704 (2d Cir.), vacated as moot, 320 U.S. 707 (1943). The phrase has now come to refer to a civic-minded person who brings suit to prevent or correct official misconduct. See Dawson, Lauyers and Involuntary Clients in Public Interest Litigation, 88 HARV. L. REV. 849, 888 (1975).

5421 U.S. 240 (1975). See generally Comment, After Alyeska: Will Public Interest Litigation Survive?, I6 Santa Clara L. Rev. 267 (1976); Note, Alyeska Pipeline Service Co. v. Wilderness Society: Demise of the "Private Attorney General", 6 ENvr'L Law 243 (1975); 6 Cum. L. Rev. 481 (1975).

${ }^{6}$ See text accompanying notes 107-117 infra.

${ }^{7} 535$ F.2d 1318 (D.C. Cir. 1976) (per curiam).

${ }^{8} 42$ U.S.C. $\$ \S 1857-57 l$ (1964).

942 U.S.C. $\$ \$ 1857-58 \mathrm{a}$ (1970), amending 42 U.S.C. $\$ \$ 1857-571$ (1964). 
was legitimate and beneficial to the public interest. ${ }^{10}$ The District of Columbia Circuit Court of Appeals, however, held that although the citizen suit provision confers jurisdiction over government entities qua polluters, it does not reach government regulators qua se. Given the defect in jurisdiction over the District of Columbia defendants, the fee award against them was reversed. The circuit court gave no consideration to the possibility that fee shifting might be justified under one of the traditional equitable exceptions that survive Alyeska. ${ }^{11}$

Because the Georgetown decision may discourage public interest suits to enforce the Clean Air Act, this Comment will analyze critically its holding regarding attorneys' fee awards. The court's construction of the citizen suit provision as precluding statutory fee shifting against government officials alleged to have failed their duty under the Act to regulate polluters will be shown to be unnecessarily narrow. A more liberal reading is consistent with congressional intent. Further, this Comment will show that equitable fee shifting is permissible in these factual circumstances under the established "substantial common benefit" exception to the American rule.

Before reaching these conclusions, it is necessary first to explore in more detail the express authorization of fee shifting in the citizen suit provision of the Clean Air Amendments, and the relevant aspects of the court opinions in Georgetoun.

\section{The Citizen Suit Under the Glean Air Amendments}

Since the passage of the Clean Air Act in $1963^{12}$ the role of the federal government in the control of air pollution has become increasingly important. ${ }^{13}$ The Clean Air Amendments of 1970 not only granted the federal government ${ }^{14}$ extensive stan-

${ }^{10}$ Citizens Association of Georgetown v. Washington, 383 F. Supp. 136, 143 (D.D.C. 1974).

11535 F.2d at 1320. Plaintiffs' counsel failed to make an argument for an equitable exception.

12 The Clean Air Act was the first federal air pollution control legislation. A prior act, the Air Pollution Control Act of 1955, ch. 360, 69 Stat. 322, had placed responsibility for air pollution exclusively in the hands of the individual states. On the federal level, it merely provided for research and technical assistance to aid in such control.

${ }^{13}$ See Kramer, The 1970 Clean Air Amendments: Federalism In Action or Inaction?, 6 Tex. TECH U.L. Rev. 47 (1974). See generally Schroeder, Pollution in Perspective: A Survey of the Federal Effort and the Case Approach, 4 NAT. Resources LAw. 381 (1971).

${ }^{14}$ The implementation of this legislation was originally the responsibility of the Department of Health, Education, and Welfare. After the establishment of the Environmental Protection Agency, the functions vested in the Secretary of HEW were transferred to the Administrator of the EPA. Reorganization Plan No. 3 of 1970, § 2(a)(3), 84 Stat. 2086 (1970). 
dards-setting, ${ }^{15}$ regulatory, ${ }^{16}$ and enforcement authority, ${ }^{17}$ but also added the citizen suit provision of section $304 .{ }^{18}$

Section 304 allows a private citizen to commence a civil action in federal district court, without regard to the amount in controversy or citizenship of the parties, against any personincluding the Government-for violation of an emission standard, limitation, or order. ${ }^{19}$ A private citizen may also bring suit against the Administrator of the Environmental Protection Agency for failure to carry out any non-discretionary act required of him. ${ }^{20}$ The citizen suit provision permits the court to award the costs of litigation, including reasonable attorney and expert witness fees, to any party where "such award is appropriate." 21 By making every person a potential law enforcer, this provision ameliorates the problem of inadequate government enforcement due to insufficient manpower and resources. ${ }^{22}$

The citizen suit provision "is carefully restricted to actions where violations of standards and regulations or a failure on the part of officials to act are alleged." ${ }^{33}$ Section 304 also does not specifically allow a damage remedy; ${ }^{24}$ this may mean that citizen suits are limited in the federal courts to actions for injunctive relief. ${ }^{25}$ Additionally, the provision imposes severe procedural requirements concerning the exhaustion of administrative rem-

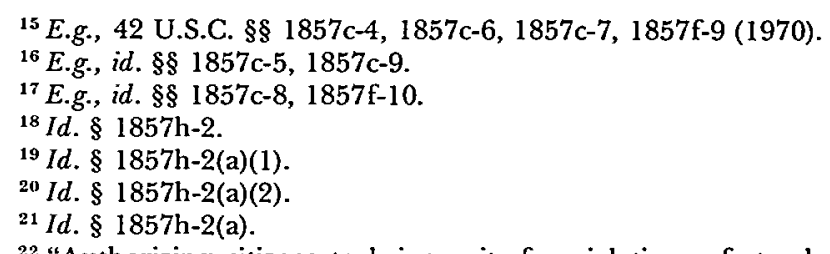

22 "Authorizing citizens to bring suits for violations of standards should motivate governmental agencies charged with the responsibility to bring enforcement and abatement proceedings." S. REP. No. 1196, 9 Ist Cong., 2d Sess. 36-37 (1970).

${ }^{23}$ S. ReP. No. 1196, 9 Ist Cong., 2d Sess. 36 (1970). Defining the limits of citizen suit jurisdiction becomes significant because the scope of such jurisdiction in turn defines the limits of statutory fee-shifting. See notes 47-60 infra \& accompanving text.

2442 U.S.C. § $1857 \mathrm{~h}-2$ (1970). Both Senator Muskie, who introduced the 1970 Amendments, and Senator Hart expressed on the floor of the Senate their intentions that the Amendments not allow for damage suits. I16 Cong. REC. 33102 (1970) (remarks of Senator Muskie); id. 33104 (remarks of Senator Hart).

${ }^{25}$ Note, The Clean Air Amendments of 1970: Better Automotive Ideas From Congress, 12 B.C. IND. \& Com. L. Rev. 571, 614 (1971); Note, Federal Pollution Control: Participation by States and Individuals Enhances The National Pollution Control Effort, 16 ViLL. L. REv. 827, 841 (1971). The language of 42 U.S.C. $\$ 1857 \mathrm{~h}-2$ (e) (1970) can be interpreted as both permitting and denying suits for damages in the federal courts. For a discussion of the arguments pro and con, see Note, Enforcement of the Clean Air Amendments of 1970, 48 Notre Dame Law. 921, 931-33 (1973). 
edies. ${ }^{26}$ If a citizen suit does satisfy these restrictions, however, section 304 authorizes discretionary fee shifting by the court. Moreover, by authorizing the court to award attorneys' fees and costs to either party this provision makes the citizen suit a viable remedy for public interest litigants with valid enforcement claims or injunctive relief while discouraging frivolous or harassing actions. ${ }^{27}$

\section{The Georgetown Opinions}

Plaintiff citizen groups ${ }^{28}$ brought suit under section 304 of the Clean Air Amendments to enjoin construction of two office buildings. Joined as defendants were the private corporate builders and the public officials responsible for the regulation of pollution in the District of Columbia. ${ }^{29}$ The basic complaint was that automobiles parking in the buildings' garages would generate significant air pollution. ${ }^{30}$ Plaintiffs argued two alternative theories of relief, but lost in the district court on the merits. Plaintiffs first argued that the buildings were "stationary sources" of pollution, and therefore, the District of Columbia's air quality implementation plan $^{31}$ required a review of potential

${ }^{26} 42$ U.S.C. $\$ 1857 \mathrm{~h}-2(\mathrm{~b})(1970)$ requires sixty days notice be given to the Administrator, the state control agency, and the alleged polluter prior to bringing a citizen suit. The purpose of this notice requirement is to delay any citizen suit in order to give appropriate officials time to act. S. REP. No. 1196, 9 lst Cong., 2d Sess. 37 (1970); City of Highland Park v. Train, 519 F.2d 681, 690-91 (7th Cir. 1975), cert. denied, 424 U.S. 927 (1976). Consequently, failure to give such notice does not necessarily cause the suit to be barred forever. Although an action commenced before giving notice will be dismissed, plaintiff may then give notice and file suit with the same allegations. If the responsible officials file suit, the private action is barred (with certain exceptions), but the complaining party may intervene if the suit is in federal court. 42 U.S.C. $\S$ 1857h-2(b)(1)(B) (1970). Metropolitan Washington Coalition for Clean Air v. District of Columbia, 373 F. Supp. 1089, 1092 (D.D.C. 1974), rev'd on other grounds, 511 F.2d 809 (D.C. Cir. 1975).

${ }^{27} 42$ U.S.C. $\$ 1857$ h-2(d) (1970). See S. ReP. No. 1196, 9lst Cong., 2d Sess. 38 (1970).

${ }^{28}$ The Citizens Association of Georgetown, founded in 1878, is organized to preserve the historical and scenic values of Georgetown for many years. The Committee of 100 on the Federal City, founded in 1923, is generally committed to improving the human environment of the nation's capital. $383 \mathrm{~F}$. Supp. at 138.

${ }^{29}$ The local government defendants were Walter E. Washington, the Commissioner of the District of Columbia; Julian R. Dugas, the Director of the D.C. Department of Economic Development; and William C. McKinney, the Acting Director of the D.C. Department of Environmental Services. Id.

${ }^{30}$ The lower court found that this alleged detriment to the health of the individual plaintiffs, and the potential loss to the corporate defendants if the plaintiffs succeeded in this suit were in excess of $\$ 10,000.00$. Id.

${ }^{31}$ District of Columbia Air Quality Control Regulations, \$ 8-2:720(a), [1976] Exvir. REP. (BNA) 341:0501. 
pollution impact and the issuance of air quality permits preceding construction. ${ }^{32}$ The district court found that the corporate defendants had not violated an emission standard or limitation. ${ }^{33}$ Although EPA regulations promulgated subsequent to the commencement of construction of the buildings extended the category of stationary sources to embrace "indirect sources," including parking facilities, these regulations were not given retroactive effect. $^{34}$ Consequently, the district court held that the first theory failed as a matter of law. ${ }^{35}$ Plaintiff's second theory of relief was that by 1977 the increased automobile traffic associated with the projects would result in pollution levels in violation of the applicable ambient air regulations. ${ }^{36}$ In view of the formidable problems of proof, it was not surprising that plaintiffs failed as a matter of fact under this second theory. ${ }^{37}$

Notwithstanding plaintiffs' defeat on the merits, the district court made a pro rata assessment against the government de-

${ }^{32}$ Id. 341:0509.

${ }^{33} 383$ F. Supp. at 139 . The court also held that this finding did not effect its decision that the citizen suit provision vested jurisdiction in the court.

3440 C.F.R. $\$ 51.18$ (a) (1976). The District of Columbia Implementation Plan required by $\S 110$ of the Clean Air Act, 42 U.S.C. $\$ 1857 \mathrm{c}-5$ (1970), was approved by the EPA and went into effect in 1972. Subsequent events determined, however, that this plan was incomplete and had elemental shortcomings in the attainment and maintenance of the required national ambient air quality standards. Consequently, the EPA withdrew approval of the maintenance provisions of the D.C. plan. 38 Fed. Reg. 12,920 (1973). The legislative background of air pollution control in the District of Columbia pertinent to this case is set out in detail in Citizens Ass'n of Georgetown v. Washington, 370 F. Supp. 1101, 1105-06 (D.D.C. 1974).

The District plan was exempt from the requirement of indirect source review procedures, 383 F. Supp. at 141 , and the District did not institute such procedures on its own volition prior to the withdrawal of EPA approval. In the absence of a valid local plan, the Administrator was required by $\S 110$ of the Clean Air Act to promulgate the regulations implementing these indirect source review procedures. 42 U.S.C. $\$ 1857 \mathrm{c}-5$ (c)(1)(C) (1970). Pursuant to an order by the District of Columbia Circuit in National Resources Defense Council, Inc. v. EPA, 475 F.2d 968, 971 (D.C. Cir. 1973), as modified, November 8, 1973, the Administrator established a procedure for reviewing some indirect sources in the District. See 40 C.F.R. $\$ 52.493$ (1976). These regulations apply to the construction or modification of certain parking facilities in the District. Id. $\S 52.493$ (c). The Administrator, motivated by equitable considerations, decided that these review procedures would not apply to any project where construction had commenced prior to the actual promulgation of these rules. Thus, these regulations only apply to parking facilities with more than 250 spaces whose construction or modification had commenced after November 12, 1973. 38 Fed. Reg. 31,536 (1973). Consequently, these regulations were inapplicable to the corporate defendants' projects because the corporate defendants began construction prior to November 13, 1973. $383 \mathrm{~F}$. Supp. at 141 .

${ }^{35} 383$ F. Supp. at 141.

${ }^{36} I d$. at $138-139$.

37 "Plaintiffs' evidence about the air quality in the Georgetown area in 1977 is speculative, conflicting and inadequate to support a judgment." Id. at 142. 
fendants for one-third of plaintiffs' attorneys' fees. ${ }^{38}$ The justification for the award was that "various actions and failures to act [by the government officials] have been the principal cause of the present litigation." "39 The court found authority to make the award in section 304 of the Clean Air Act ${ }^{40}$ and noted that this authority was unaffected by plaintiffs' failure on the merits. ${ }^{41}$ The appropriateness standard conditioning fee awards under section 304 was met because the suit had benefitted the public interest as defined in the Clean Air Act. ${ }^{42}$ In particular, the litigation prompted action "in the face of a clean air regulatory vacuum in the District." ${ }^{33}$ In the district court's view the congressional mandate to the District of Columbia to meet the Clean Air Act's 1977 deadline for compliance with national air quality standards imposed upon the District officials a "continuing obligation to act." 44 The court concluded that the suit had benefitted the public interest under the Act by educating the public regarding the District's laxity in fulfilling this obligation. ${ }^{45}$

The District of Columbia Circuit heard the case on appeal

${ }^{38} I d$. at 145. Plaintiffs did not seek costs or attorneys' fees from the corporate defendants because the district court determined that they had not violated the law. Although such a determination did not necessarily preclude an assessment of attorneys' fees against these defendants, the plaintiffs chose to make no claim against them. Brief for Appellees at 28. Additionally, 'because a large portion of the attorneys' work in this litigation related to the [corporate] defendants, plaintiffs requested that the district court assess the District of Columbia for only its proportionate share of plaintiffs' costs, including attorneys' fees." $383 \mathrm{~F}$. Supp. at 144.

${ }^{39} 535$ F.2d at 1320 (quoting Brief for Appellees at 24).

40 383 F. Supp. at $143-44$.

41 "The plain meaning of 42 U.S.C. $\S 1857 \mathrm{~h}-2(\mathrm{~d})$ is that success or failure on the merits has nothing to do with the trial court's power to award . . . attorneys' fees in citizen suits under the Clean Air Act." 383 F. Supp. at 144. The legislative history bears out this interpretation: "The court may award costs of litigation to either party whenever the court determines that such an award is in the public interest without regard to the outcome of the litigation." S. REP. No. 1196, 91st Cong., 2d Sess. at 65.

42383 F. Supp. at 14446 .

43 Id. at 145 .

44 Id.

45 Id. The court explained further:

In order to understand the public benefit conferred by this suit, it is necessary to understand the basic design of the Clean Air Act. The structure of the Act evidences the Congressional intent to rely on state and local governments for implementation of control programs necessary to abate air pollution. 42 U.S.C. $\$ 1857 c-5$. Where this reliance is frustrated by inaction, as is the case with the District government, the locality is in imminent danger of one, and perhaps both, of two unpleasant eventualities: 1) failure to attain air quality standards requisite for good health, or 2) assumption by the federal government of the task of effecting local air pollution control programs. See 42 U.S.C. $\$ \S 1857 \mathrm{c}-4(\mathrm{~b}), 1857 \mathrm{c}-5(\mathrm{c})$. In the latter case, the air quality control program Id. may not be responsive to particular, local needs. 
after the Supreme Court had rendered its decision in Alyeska. ${ }^{46}$ In light of Alyeska's contraction of judicial power to shift attorneys' fees, the circuit court carefully scrutinized the source of authority for the district court award-section 304. Section 304(d) authorizes fee shifting "in any action brought pursuant to [section 304(a)] . . to to any party, whenever the court determines such award is appropriate." 47 The crucial prerequisite to authority to shift fees under section 304(d), therefore, is that the underlying action be "pursuant to" section 304(a). Section 304(a) provides in relevant part that "any person may commence a civil action on his own behalf ... against any person (including ... any ... governmental instrumentality ... to the extent permitted by the Eleventh Amendment . . .) who is alleged to be in violation of ... an emission standard or limitation." ${ }^{8}$ The circuit court construed the foregoing language of section 304(a) in light of its legislative history as reaching a governmental instrumentality only qua polluter and not qua regulator. ${ }^{49}$ In making this construction the court gave weight to a drafting change in the section prior to its enactment:

Although early versions of the legislation gave the district courts jurisdiction over civil actions "for . . . enforcement, or to require such enforcement," whenever a government instrumentality was alleged to be in violation of "any ... protision" of the Act, ... the enacted version . . . confers federal jurisdiction only over suits against polluters, and under certain conditions, the Administrator of the EPA. ${ }^{50}$

Thus the court concluded that "an allegation that a government instrumentality has failed to enforce the Clean Air Act does not

${ }^{46}$ The Alyeska opinion was handed down on May 12, 1975. Although this was after the briefs were submitted in the instant case, it was prior to the oral argument made on October 16, 1975.

${ }^{47} 42$ U.S.C. $\$ 1857 \mathrm{~h}-2(\mathrm{~d})(1970)$.

${ }^{48} 42$ U.S.C. $\$ 1857 \mathrm{~h}-2(\mathrm{a})(1970)$.

49535 F.2d at $1320-21$. The court noted that the complaint did not allege that any District of Columbia facility was emitting pollutants into the air; rather, it only alleged that the District failed to require preconstruction review of private buildings with large parking garages. After specifying the relevant components of the statutory definition of "emission standard or limitation", the court employed the appropriate definitions of these separate components to demonstrate that the complaint could not be read to allege that the District was in violation of an "emission standard or limitation." Id. at 1321-22.

${ }^{50} 535$ F.2d at 1320-21 (footnote omitted). The court qualified this statement by saying that it did not mean to imply that it was the intent of Congress in the earlier versions to authorize district court jurisdiction over actions such as this one. Id. at 1321 n.3. 
satisfy the statutory requirement that the government instrumentality be alleged to be in violation of 'an emission standard or limitation.' "51

Under the two theories of relief ${ }^{52}$ the lower court had asserted jurisdiction over the public defendants alternatively under section 304(a) or under federal question jurisdiction. ${ }^{53}$ The gist of the complaint against the District of Columbia under either theory, however, was that it had failed its obligation under the Act to regulate polluters. District officials in their capacities as regulators had not instituted "preconstruction review" of private buildings with large parking facilities. ${ }^{54}$ No allegation that the District itself was polluting in violation of the Act was made. ${ }^{\mathbf{5 5}}$ Having construed section 304 (a) as reaching only polluters, the circuit court held that jurisdiction over the District officials was improperly extended. ${ }^{56}$

In the absence of section 304(a) jurisdiction over the defendants, the circuit court felt constrained to reverse the award of attorneys' fees. ${ }^{57}$ The federal question jurisdiction, although valid, could not support the award because the jurisdictional statute lacked an express authorization as required by Alyeska. ${ }^{\mathbf{5 8}}$

\section{Less Restrictive Judicial ApProaches}

\section{A. Unfortunate Ramifications of the Georgetown Decision}

The Georgetown decision will undoubtedly have a discouraging impact on public interest suits under section 304 to enforce the Clean Air Act. Damage relief may well be unavailable in section 304 suits; ${ }^{59}$ therefore, the fee shifting provision in section $304(d)$ is a crucial encouragement to citizen suits for injunctive relief. Absent fee awards the prospect of bearing the

51 Id. at 1320 .

52 See notes 31-37 supra \& accompanying text.

${ }^{53}$ See 383 F. Supp. at 138-39. Regarding federal question jurisdiction, 28 U.S.C. $\S 1331(\mathrm{a})(1970)$, the court concluded:

A substantial federal question exists as to whether the Clean Air Act in its entirety requires that the Maloney and Inland Developments be reviewed by a federal district court, prior to or during construction, to determine if construction will interfere with the attainment and maintenance of the national ambient air quality standards in the District by May $31,1977$.

Id. at 139 .

54535 F.2d at 1320. For a discussion of the possible obstacle to citizen suits against public officials qua regulators posed by the tenth amendment, see note 137 infra.

55 Id.

56 $I d$. at 1322 .

57 Id. at 1323 .

${ }^{58} \mathrm{Id}$. at 1320 .

${ }^{59}$ See notes 24-25 supra \& accompanying text. 
entire litigation expenses will deter private enforcers from bringing suits to curtail pollution. Georgetown removes this encouragement to citizen suits against private polluters in circumstances under which it is arguably most necessary-cases in which the local regulators themselves are not fulfilling their obligation under the Act to regulate polluters. ${ }^{60}$

The circuit court remarked that "our conclusion does not leave the public without a remedy when a state fails to meet its responsibilities under the Clean Air Act." 61 The court, however, neglected to evaluate the effectiveness of these alternative measures. For example, the court noted that the Administrator of the EPA has the authority to implement corrective measures if a state fails to submit or enforce an adequate implementation plan. ${ }^{62}$ Relying on the Administrator to promulgate regulations, however, has significant drawbacks. Intervention by the Administrator could result in the implementation of a program that is unresponsive to local needs ${ }^{63}$ or incomplete because of equitable considerations arising from the delay in its promulgation. ${ }^{64}$ Consequently, the locality may be unable to attain the proper air quality standards within a reasonable time period. The circuit court also suggested that a private citizen could seek relief in a federal or state court based on a jurisdictional grant other than the citizen suit provision. The court, however, did not suggest an alternative source of jurisdiction that allowed for fee shifting $^{65}$-an important incentive to environmental interest litiga-

6" Even though the plaintiffs lost on the merits, theoretically attorneys fees could have been taxed nevertheless to the private corporate defendants. See note 41 supra \& accompanying text. As jurisdiction over the corporate defendants was properly pursuant to $\$ 304$ (a), such an award would not be precluded by the circuit court's narrow construction of $\S 304(\mathrm{~d})$. The problem is that such an award probably would not have been appropriate as required by $\$ 304(\mathrm{~d})$, because the plaintiffs alleged that the District was principally responsible for the litigation. See text accompanying note 39 supra. Thus in future cases that are factually similar, even should plaintiffs succeed on the merits (regarding "success" in this context, see notes 119-23 infra \& accompanying text), the possibility remains, depending upon the extent of the culpability of the local regulators, that no award or only a partial taxing of attorneys fees against the private defendants will be appropriate. Georgetoun would bar these future plainuffs from recovering fees from the negligent public regulator, the appropriate party to tax. The local regulator is the appropriate party to tax because taxing local government funds fairly distributes the cost of the suit to its true beneficiaries-the members of the local public. For a similar analysis under the substantial common benefit rationale, see notes 132-38 infra $\&$ accompanying text.

61535 F.2d at 1323 .

${ }^{62} I d$.

${ }^{63}$ See note 45 supra.

64 See note 34 supra.

${ }^{65} 535$ F.2d at 1323 . The only alternative that the court suggested was 28 U.S.C. 
tion that seeks injunctive relief.

Another alternative course of action for plaintiffs in Georgetown was direct judicial review of the implementation plan by the court of appeals pursuant to Section 307(b)(1) of the Clean Air Act. ${ }^{66}$ The plaintiffs could have then specifically challenged the provision exempting the corporate defendants' building projects. ${ }^{67}$ The court of appeals, however, would be required to affirm the Administrator's decision unless the conclusions reached were "arbitrary or capricious." 68 Given the complexity of competing interests in establishing implementation plans, it is highly doubtful that a court could make such a finding in the face of the Administrator's expertise. ${ }^{69}$ Additionally, this review would not involve the District of Columbia government and the public would not be informed about the District's alleged negligence in pollution regulation. Moreover, in the view of many courts section 307 does not authorize fee shifting; ${ }^{70}$ plaintiffs are then forced to pay their own attorneys' fees regardless of the outcome of the proceedings. In sum, this procedure is an inadequate substitute for litigation brought pursuant to the citizen suit provision.

Contrary to the view of the circuit court, the Georgetoum holding barring fee shifting on its facts leaves future plaintiffs with only ineffective alternative remedies. Because of the crucial role fee awards play in encouraging citizen suits to enforce the Act, avoiding the Georgetown result in future cases presenting similar factual circumstances is highly desirable.

$\S 1331$ (1970) (federal question jurisdiction). As the court previously noted, however, this provision "will not support a claim for attorneys' fees." Id. at 1320; see text accompanying note 58 supra.

${ }_{66} 42$ U.S.C. \& $1857 \mathrm{~h}-5(\mathrm{~b})(1)(1970)$.

${ }^{67}$ See note 34 supra. The exemption provision is an integral part of the regulation reviewable only in the court of appeals. City of Highland Park v. Train, 519 F.2d 681, 688-89 (7th Cir. 1975)(citing cases).

${ }^{68}$ E.g., South Terminal Corp. v. EPA, 504 F.2d 646 (1st Cir. 1974); Friends of the Earth v. EPA, 499 F.2d 1118 (2d Cir. 1974); Texas v. EPA, 499 F.2d 289 (5th Cir. 1974).

${ }^{69}$ See, e.g., Citizens Ass'n of Georgetown v. Washington, 370 F. Supp. 1101, 1108-09 (D.D.C. 1974).

${ }^{70}$ Natural Resources Defense Council, Inc. v. EPA, 512 F.2d 1351 (D.C. Cir. 1975); $c f$. Shannon v. United States Dep't of Housing and Urban Dev., 409 F. Supp. 1189 (E.D. Pa. 1976) (plaintiff suing under section 808 of Title VIII of the Civil Rights Act of 1968 could not be awarded attorneys' fees pursuant to section 812(c) of the Act because section 812 only applies, by its own terms, to suits commenced for violations of sections 804-06). But see Natural Resources Defense Council, Inc. v. EPA, 484 F.2d I331 (1st Cir. 1973); but of. Sosa v. Fite, 498 F.2d 114, 121-22 (5th Cir. 1974) (plaintiff suing under section 1635 of the Truth in Lending Act could be awarded attorneys' fees although fee shifting was only authorized in suits brought pursuant to section 1640). 


\section{B. Liberal Interpretation of the Citizen Suit Provision}

An award of attorneys' fees to plaintiffs in Georgetown could have been justified under a liberal interpretation of section 304(d), which authorizes fee shifting "to any party" in an action brought "pursuant to [section 304(a)]." The circuit court impliedly restricted "any party" to mean "any party over whom section 304(a) jurisdiction is properly asserted." The liberal interpretation would construe "any party" to include in certain circumstances parties properly joined to a section 304(a) action although under a separate source of jurisdiction. For example, because section 304(a) jurisdiction was properly asserted over the corporate defendants in Georgetown, the action was in this sense "pursuant to" section 304(a); because the District officials were properly joined under federal question jurisdiction, authority exists for an award of attorneys' fees. This broad construction of section 304(d) is not foreclosed by the Supreme Court decision in Alyeska and, furthermore, it is consistent with congressional intent as evidenced in the legislative history of section 304.

The concern of the Supreme Court in Alyeska was to eliminate judicial awards of attorneys' fees under a private attorney general theory absent an express congressional authorization. ${ }^{71}$ Congress, however, has explicitly recognized the important public interests involved in section 304 citizen suits. Were a court to adopt the proposed liberal construction of section 304(d), it would not be deciding which congressional policies are important enough to warrant fee shifting-the judicial practice condemned by Alyeska; rather, it would be exercising an unquestioned judicial prerogative to determine the scope of the statutory fee awards authorization.

In reversing the lower court award of fees, the circuit court looked to the legislative history of section 304(a). This legislative history-for example the drafting change undergone by the section $^{72}$ - supports the court's conclusion that only polluters are subject to section 304(a) jurisdiction. ${ }^{73}$ The proposed construction of section 304(d), however, does not involve any expansion of federal jurisdiction under section $304(\mathrm{a}) ;{ }^{74}$ rather, it merely

${ }^{71}$ See text accompanying note 116 infra.

${ }^{72}$ See text accompanying notes 49-50 supra.

${ }^{73}$ The Administrator of the EPA, however, is subject to $\S 304$ (a) jurisdiction where it is alleged that he has failed to perform a non-discretionary duty. 42 U.S.C. $\S$ 1857h-2(a)(2) (1970). This single express exception extending $\$ 304(a)$ jurisdiction over a regulator who has failed his duty to regulate renders all the more persuasive the court's conclusion that $\$ 304$ (a) does not reach other neglectful regulators.

${ }^{74}$ The legislative history implies that in its explicit drafting of $\S 304(a)$ Congress 
authorizes fee shifting against a party who, although not subject to section 304(a) jurisdiction, is nonetheless properly joined to the action under an independent jurisdictional grant. The legislative history is silent as to whether the scope of section 304(a) jurisdiction strictly limits the parties against whom fees may be assessed. ${ }^{75}$ It does indicate, however, that fee awards may be made to losing parties, and this suggests, if anything, that it was intended to give courts broad discretion in applying section 304(d).

One problem in applying the proposed construction of section $304(\mathrm{~d})$ is avoiding an assessment against a defendant joined to a section 304 citizen suit purely for that purpose. This problem can be remedied if, as a prerequisite to assessing a party joined under a jurisdictional grant other than section 304(a), the courts require that such party be "inextricably involved" with the subject matter of the suit properly brought pursuant to section 304(a). For example, the inextricably involved requirement was satisfied in Georgetown. Although plaintiffs failed to meet their burden of proof, the district court held that the suit against the corporate defendants was non-frivolous. ${ }^{76}$ Section 304(a) jurisdiction over the corporate defendants was never challenged; ${ }^{77}$ plaintiffs' suit, therefore, was properly brought pursuant to section 304(a). The central allegation of plaintiffs' complaint, however, charged the District officials, who were joined under federal question jurisdiction, with primary responsibility for forcing a resort to judicial remedy by failing to fulfill their duty under the Clean Air Act. Again, the undisturbed district court findings supported the substantiality of the nonfeasance allegation. ${ }^{78}$ The public defendants were, therefore, inextricably involved in the subject matter of plaintiffs' suit brought pursuant to section

intended to place well-defined limits on that section's expansion of federal jurisdiction. See S. Rep. No. 1196, 91 st Cong., 2d Sess. 36-39 (1970). The circuit court noted: "Congress did not fling the courts' door wide open ...." 535 F.2d at 1321 (quoting Natural Resources Defense Council, Inc. v. Train, 510 F.2d 692, 700 (I975)).

${ }^{75}$ See S. Rep. No. 1196, 91 st Cong., 2d Sess. 36-39, 65; H.R. Rep. No. 1783, 91 st Cong., 2d Sess. 55-56, reprinted in [1970] U.S. Code Cong. \& Ad. News 5374, 5388. One senator has remarked that the question of attorneys' fees often fails to even come up in legislative debate because the major concern is focused on other issues in the legislation. See Tunney, Foreward: Financing the Costs of Enforcing Legal Rights, $122 \mathrm{U} . \mathrm{P}_{\mathrm{A}}$. L. REv. 632, 633-34 (1974). For a compilation of the legislative history of the amendments to the Act generally, see ENviromental Policy Division of the Congressional. Research Service, A Legislative History of the Clean Air Amendments of 1970 (1974).

\footnotetext{
${ }^{76} 383$ F. Supp. at 145.

${ }^{77}$ See note 33 supra.

${ }^{78}$ See notes $42-45$ supra \& accompanying text.
} 
304(a), and thus were appropriate parties for assessment of fees. In this manner the inextricably involved test can operate to define the outer limits of appropriate fee shifting under section 304(d). ${ }^{79}$

Because the liberal construction of section 304(d) is consistent with Alyeska and the legislative history of section 304, and in light of the unfortunate ramifications of the strict approach taken by the Georgetown court, the liberal interpretation should be adopted by the courts when presented with factually similar cases. ${ }^{80}$

\section{Equitable Exceptions to the American Rule}

\section{The History of Fee Awards}

Except for the minimal amounts that may be taxed as costs in the nature of "docket fees," 81 attorneys' fees are as a general rule not taxable against losing parties in suits brought in federal court. ${ }^{82}$ The American rule, however, has never acted as a com-

${ }^{79}$ Even if the inextricably involved test is met, the issue will nonetheless remain whether taxing the defendants joined under separate jurisdictional grants to the section 304 citizen suit is appropriate. This issue of appropriateness, however, must also be explored even in the case of section 304(a) parties.

${ }^{80}$ Precedent exists for broadly applying $\S 304(d)$ to parties not within $\S 304(\mathrm{a})$ jurisdiction. See Natural Resources Defense Council, Inc. v. EPA, 484 F.2d 1331 (1st Cir. 1973). In that case plaintiffs sued the Administrator of the EPA in the First Circuit Court of Appeals under $\S 307,42$ U.S.C. $\S 1857 \mathrm{~h}-5$ (1970), using jurisdiction in a "petition for review of the Administrator's action in approving or promulgating any implementation plan." Id. (b)(1). Because of the close connection in subject matter between $\S 307$ suits and $\S 304(a)(2)$ suits against the Administrator for failure to perform nondiscretionary duty, 42 U.S.C. $\$ 1857 \mathrm{~h}-2$ (a)(2) (1970)-as evidenced in the legislative history of the two sections-the First Circuit held the $\S 307$ action to be pursuant to $\S$ 304(a) and so justified a $\S 304$ (d) award of fees. 484 F.2d at 1335-38. For authority rejecting fees awards in $\S 307$ actions, see Natural Resources Defense Council, Inc. v. EPA, 512 F.2d 1351 (D.C. Cir. 1975).

8128 U.S.C. $\S \S 1920,1923$ (a) (1970). For the history of these docket fees provisions and their relationship to the American rule, see Alyeska Pipeline Serv. Co. v. Wilderness Soc'y, 421 U.S. 240, 247-60 (1975).

${ }^{82}$ See note 9 supra. Among the justifications most often given for the American rule are the following: (1) it encourages resolution of controversies through the courts by removing the threat of paying an adversary's counsel fees; (2) it avoids the time, expense, and difficulty of proof inherent in determining reasonable attorneys' fees; (3) it avoids penalizing one who chooses to prosecute or defend a lawsuit; (4) the contrary rule floods courts with litigation. See Fleischman Distilling Corp. v. Maier Brewing Co., 386 U.S. 714, 718 (1967); See also 6 J. Moore, Federal Practice If 54.70[2], at 1304 (2d ed. 1975).

A number of attacks on the American rule have been made. See, e.g., King \& Plater, The Right to Counsel Fees in Public Interest Environmental Litigation, 41 TENN. L. REv. 27 (1973); Kuenzel, The Attorney's Fee: Why Not a Cost of Litigation?, 49 Iowa L. Rev. 75 (1963); McLaughlin, The Recovery of Attorney's Fees: A Neu' Method of Financing Legal 
plete bar against awarding attorneys' fees to the prevailing party; the rule has been subject to a number of exceptions, both statutory and equitable. ${ }^{83}$ The statutory provisions may: (1) provide mandatory ${ }^{84}$ or discretionary ${ }^{85}$ awards to the successful plaintiff; (2) permit discretionary awards to the prevailing party; ${ }^{86}$ or (3) permit awards "to any party, whenever the court determines such award is appropriate." 87 Under the equitable exceptions, federal courts employ their historical equity powers to award fees when "the interests of justice so require." 88 The equitable exceptions include: (1) obdurate behavior, (2) common fund, and (3) substantial common benefit.

The obdurate behavior theory allows courts to award counsel fees to a litigant whose opponent has pursued a clearly unfounded action or defense and has done so "in bad faith, vexati-

Services, 40 Fordham L. Rev. 761 (1972); Stoebuck, Counsel Fees Included in Costs: A Logical Development, 38 U. Colo. L. Rev. 202 (1966); Comment, Court Awarded Attorney's Fees and Equal Access to the Courts, 122 U. PA. L. Rev. 636, 648-55 (1974); Note, Attorney's Fees: Where Shall the Ultimate Burden Lie?, 20 VAND. L. Rev. 1216 (1967).

${ }^{83}$ Fees may also be shifted where parties to a contract have made specific provision therefor. Fleischmann Distilling Corp. v. Maier Brewing Co., 386 U.S. 714, 717 (1967); McCormick, Counsel Fees and Other Expenses of Litigation as an Element of Damages, 15 MinN. L. Rev. 619, 636-37 (1931); see generally 2 S. SPEISER, ATtorneys' Fees 283-367 (1973). Some states have codified this common law exception with the added qualification that such contracts be enforced reciprocally. E.g., CAL. Civ. Code $\$ 1717$ (West 1973).

${ }^{84}$ See, e.g., Packers and Stockyards Act of 1921, § 309(f), 7 U.S.C. \$ 210(f) (1970); Perishable Agriculture Commodities Act of 1930, $\$ 7$ (b), 7 U.S.C. $\$ 499 \mathrm{~g}(\mathrm{~b})$ (1970); Bankruptcy Act of 1898, § 64, 11 U.S.C. $\S 104(a)(1)$ (1970); Clayton Act $\S 4,15$ U.S.C. $\S 15$ (1970); Federal Trade Commission Act $\S 801,15$ U.S.C. $\S 72$ (1970); Truth in Lending Act $\S 130(\mathrm{a})(2), 15$ U.S.C. $\$ 1640(\mathrm{a})(3)$ (Supp. II 1974); Consumer Product Safety Act $\$ 24,15$ U.S.C. $\$ 2073$ (1970); Organized Crime Control Act of 1970, $\S 901$ (a), 18 U.S.C. $\$ 1964$ (c) (1970); Fair Labor Standards Act § 16(b), 29 U.S.C. \$ 216 (b) (1970); Railway Labor Act, $\S 3(\mathrm{p}), 45$ U.S.C. $\S 153$ (p) (1970); Shipping Act of 1916; $\$ 30,46$ U.S.C. $\$ 829$ (1970); Ship Mortgage Act of 1920, $\$ 30$ (c), 46 U.S.C. $\$$ 941(c) (1970); Merchant Marine Act of 1936, § 810, 46 U.S.C. $\$ 1227$ (1970); Communications Act of 1934, $\S 206,47$ U.S.C. $\$ 206$ (1970); Interstate Commerce Act of $1887, \S \S 8,15(9), 16(2), 308(\mathrm{~b}), 49$ U.S.C. $\$ \$ 8,15(9), 16(2), 908(\mathrm{~b})(1970)$.

${ }_{85}$ See, e.g., Education Act Amendments of 1972, § 718, 20 U.S.C. $\$ 1617$ (Supp. IV 1974); Labor-Management Reporting and Disclosure Act of 1959, $\$ \$ 201$ (c), $510(\mathrm{~b}), 29$ U.S.C. $\$ \$ 431(\mathrm{c}), 501$ (b) (1970); Fair Housing Act of 1968, $\$ 812$ (c), 42 U.S.C. $\$ 3612(\mathrm{c})$ (1970).

${ }^{86}$ See, e.g., Securities Act of 1933, § 11(e), 15 U.S.C. $\$ 77 \mathrm{k}(\mathrm{e})(1970)$; Securities txchange Act of 1934, $\$ \$ 9(\mathrm{e}), 18(\mathrm{a}), 15$ U.S.C. $\$ \S 78 \mathrm{i}(\mathrm{e}), 78 \mathrm{r}(\mathrm{a})$ (1970); Patent Act, 35 U.S.C. $\$ 285$ (1970).

${ }^{87}$ Clean Air Amendments of 1970, § 304(d), 42 U.S.C. \$ 1857h-2(d) (1970); Federal Water Pollution Control Act Amendments of 1972, $\$$ 505(d), 33 U.S.C. $\$ 1365$ (d) (Supp. III 1973); Marine Protection, Research, and Sanctuaries Act of 1972, \$ $105(\mathrm{~g})(4)$, 33 U.S.C. \$ 1415(g)(4) (Supp. III 1973).

${ }^{88}$ Hall v. Cole, 412 U.S. 1, 5 (1973). For a historical development of American equity courts' power to grant fees and costs, see Guardian Trust Co. v. Kansas City S. Ry. Co., 28 F.2d 233, 240-46 (8th Cir. 1928), rev'd. on other grounds, 281 U.S. 1 (1930). 
ously, wantonly, or for oppressive reasons." 89 In recent years, the bad faith exception has been expanded to justify an award of attorneys' fees in cases where plaintiffs have been forced to seek judicial assistance in order to enjoy a clearly defined and established right. ${ }^{90}$

The common fund doctrine permits a plaintiff to recover attorneys' fees when his action results in the establishment or preservation of a fund in which others have the right to share. In order to prevent unjust enrichment, each beneficiary is indirectly charged a pro rata portion of the litigant's expenses, including attorneys' fees, by allowing the litigant to recover his expenses directly from the fund before any distribution. ${ }^{91}$ For example, in the seminal case of Trustees $\%$. Greenough,$^{92}$ the plaintiff, who sued on behalf of other bondholders to prevent waste and destruction of a fund, was held to be entitled to reimbursement of attorneys' fees from the fund. ${ }^{93}$

The three significant aspects of the common fund exception-ascertainability of the common benefit, ascertainability of the benefitted class, and existence of an equitable costspreading mechanism-form the basis of the more generalized

${ }^{89}$ F.D. Rich Co. v. Industrial Lumber Co., 417 U.S. 116, 129 (1974) (dictum) (citing Vaughan v. Atkinson, 369 U.S. 527 (1962)). This rationale may also be used to award counsel fees for the willful violation of a court order, Toledo Scale Co. v. Computing Scale Co., 261 U.S. 399, 426 (1923); and for fraud perpetrated upon the court, Universal Oil Products Co. v. Root Refining Co., 328 U.S. 575, 580 (1946) (dictum); and willful and persistent default in performing a clear statutory duty, Vaughan v. Atkinson, 369 U.S. 527, 530-31 (1962). The rationale for the exception is punitive. Hall v. Cole, 412 U.S. 1, 5 (1973).

${ }^{90}$ E.g., Cato v. Parham, 293 F. Supp. 1375, 1378 (E.D. Ark.), aff'd, 403 F.2d 12 (8th Cir. 1968); Bell v. School Board, 321 F.2d 494, 498 (4th Gir. 1963); see Comment, note 82 supra, at $660-61$.

${ }^{91}$ See, e.g., Sprague v. Ticonic National Bank, 307 U.S. 161 (1939); United States v. Equitable Trust Co., 283 U.S. 738, 745 (1931); Harrison v. Perea, 168 U.S. 311, 325-26 (1897); Central R.R. \& Banking Co. v. Pettus, 113 U.S. 116, 126 (1885). See generally Dawson, Lauyers and Involuntary Clients: Attorney Fees from Funds, 87 HARv. L. REv. 1597 (1974).

${ }_{92} 105$ U.S. 527 (1881).

${ }^{93}$ Id. at 532-34.

${ }^{94}$ See Mills v. Electric Auto-Lite Co., 396 U.S. 375, 393-94 (1970). The substantial common benefit exception may be thought of as an extention of the common fund principle:

The traditional common fund over which the court exercises its jurisdiction always represents a benefit capable of translation into money. Conceptually, however, the fund is the aggregate benefit produced by the litigation, and the court taxes any convenient resource jointly owned by the true beneficiaries. Since the court's power to award legal fees is totally independent of the existence of a fund, it is not difficult to understand the judicial development from the monetary common fund theory to the nonmonetary substantial benefit variant. To award fees under the substantial benefit rule, the court must have 
substantial common benefit exception. ${ }^{94}$ The two leading Supreme Court cases using this exception elaborated upon these three criteria. Mills v. Electric Auto-Lite Co. ${ }^{95}$ was a shareholder suit to set aside a merger procured by means of a misleading proxy solicitation in violation of the Securities and Exchange Act of 1934. ${ }^{96}$ In Hall $r$. Cole ${ }^{97}$ a former union member claimed that he was expelled from the union because he exercised his freedom of speech guaranteed by the Labor-Management Reporting and Disclosure Act. ${ }^{98}$ These cases established that (1) vindication of congressional policy, as distinguished from vindication of a concrete pecuniary interest, qualifies as an ascertainable benefit; (2) the stockholders of a corporation or the members of a union constitute ascertainable classes; and (3) taxing corporate or union funds is an equitable means of spreading costs among stockholders or union members respectively. ${ }^{99}$

Two Supreme Court decisions-Fleischmann Distilling Corp. 7. Maier Brewing Co. ${ }^{100}$ and Alyeska Pipeline Service Co. 1. Wilder-

jurisdiction over some resource which is not at issue in the litigation but which

is common to all the beneficiaries.

Note, Au'arding Attorney and Expert Witness Fees in Environmental Litigation, 58 Cornelu L. REv. 1222, 1234 (1973) (footnote omitted). Consequently, some courts have awarded attorneys' fees under the common fund exception despite the absence of pecuniary benefit. See, e.g., Kopet v. Esquire Realty Co., 523 F.2d 1005, 1008 (2d Cir. 1975). For the sake of clarity, however, the substantial common benefit rationale is treated herein as an independent exception instead of a variation of the common fund doctrine.

${ }^{95} 396$ U.S. 375 (1970).

${ }^{96} 15$ U.S.C. $\$ 78 \mathrm{n}(\mathrm{a})(1970)$.

${ }^{97} 412$ U.S. 1 (1973).

9829 U.S.C. $\$ 411$ (a)(2) (1970).

${ }^{99}$ Hall v. Cole, 412 U.S. 7 (1973); Mills v. Electric Auto-Lite Co., 396 U.S. 375 (1970). The Mills Court held that plaintiffs had succeeded in proving a violation of the proxy rules, but that remand was necessary to determine whether the corporation or the shareholders had suffered any actual injury warranting either equitable or monetary relief. Nevertheless, even if ultimately no relief would be forthcoming, the Court held that minority shareholders, "who have established a violation of the securities laws by their corporation and its officials, should be reimbursed by the corporation or its survivor for the costs of establishing the violation." Id. at 389-90. In contrast to the pecuniary benefit to the corporation required by the common fund cases, "corporate therapeutics" or vindication of statutory policy were deemed significant enough benefits under the substantial benefit exception. Id. at 392-97. In $\mathrm{Hall}$ plaintiff sought reinstatement in the union and damages. The case was brought under $\$ 102$ of the LaborManagement Reporting and Disclosure Act. 29 U.S.C. $\& 412$ (1970). Title I was enacted specifically to protect union members' freedom of speech and assembly, 29 U.S.C. $\S 411$ (a)(2) (1970); however, it contained no provision for fee shifting. The Court noted that no pecuniary injury had been shown due to the expulsion but vindication of the statute's policy substantially benefitted the union membership and thus justified taxing the union with plaintiff's attorneys' fees. 412 U.S. at 8.

Dictum indicating a substantial common benefit rationale appeared in early labor cases involving members successfully suing their unions to enforce political rights. E.g. Rolax v. Atlantic Coast Line R.R. Co., 186 F.2d 473, 481 (4th Cir. 1951).

${ }^{100} 386$ U.S. 714 (1967). 
ness Society ${ }^{101}$ - have placed significant limitations on equitable fee shifting in the context of statutory causes of action. Fleischmann raises the issue of statutory preemption of equitable power to shift attorneys' fees. The suit was for trademark infringement arising under the Lanham Act. ${ }^{102}$ Prior to the Lanham Act federal courts had unquestioned equitable power to award counsel fees in trademark infringement cases "if deliberate or willful infringement were established." 103 Section 35 of the Act prescribes an intricate set of infringement remedies in the nature of monetary relief, including a discretionary award of treble damages in some instances. No mention is made in section 35 of the possibility of fee awards. The Court held that because "Congress meticulously detailed [in section 35] the remedies available to a plaintiff who proves that his valid trademark has been infringed ... Congress intended ... [section] $35 \ldots$ to mark the boundaries of the power to award monetary relief in cases arising under the Act."104 Thus section 35's silence with regard to fees was held to preclude equitable fee shifting.

Under the short-lived private attorney general exception, judicial judgment that a public interest suit had vindicated an important congressional policy was sufficient to warrant equitable fee shifting. ${ }^{105}$ In essence the private attorney general theory raised the first criterion of the substantial benefit exception to the level of an independent basis for equitable awards of counsel fees. ${ }^{106}$

Alyeska involved a suit brought by environmental groups seeking to halt construction of the trans-Alaska oil pipeline. ${ }^{107}$ The defendants were the Secretary of the Interior, the State of Alaska, and the Alyeska Pipeline Service Co. Although congres-

101421 U.S. 240 (1975).

10215 U.S.C. \$ $1117(1970)$.

${ }^{103} 386$ U.S. at 715-16 \& nn.4 \& 5 .

104 Id. at 719-21.

${ }^{105}$ See Alyeska Pipeline Co. v. Wilderness Soc'y, 421 U.S. 240, 270 n.46 (1975) (collecting cases); Comment, supra note 82 , at 666-70.

${ }^{106}$ Because of the association of the exception with public interest litigation other elements were often present: a large beneficiary class-usually the public at large, inadequate governmental enforcement, and financial burden of private enforcement (arising in part because these suits were largely for injunctive relief as opposed to damages). See, e.g., La Raza Unida v. Volpe, 57 F.R.D. 94 (N.D. Cal. 1972); Comment, supra note 82, at 666-70.

${ }_{107}$ The suit was brought on the ground that the proposed right-of-way and special land use permits violated the statutory restrictions of the Mineral Lands and Mining Act of $1920, \S 28,30$ U.S.C. $\S 185$ (1970), and the environmental impact statement requirements of the National Environmental Policy Act of 1969, 42 U.S.C. $\S \S 4321-47$ (1970). 421 U.S. at 242-43. 
sional legislation ultimately terminated the merits of the litigation, ${ }^{108}$ upon subsequent application to the District of Columbia Circuit, one half of plaintiffs' attorneys' fees were assessed against the Alyeska Co. ${ }^{109}$ Authority to make the fee award was found in the private attorney general exception ${ }^{110}$ because the relevant statutes were silent on attorneys' fees ${ }^{111}$ and the traditional equitable exceptions were inapplicable. ${ }^{112}$ In particular, the substantial common benefit exception was unavailable because, as re-emphasized by the Supreme Court in its reversal of the award, ${ }^{113}$ neither the criterion of ascertainability of the benefitted class nor the criterion of proportionate fee spreading among the beneficiaries of the suit was present. The Supreme Court reasoned that to consider the general public of the United

${ }^{108} 421$ U.S. at 244-45. Congress amended the width requirements of the Mineral Lands and Mining Act to allow the necessary permits to be issued. Act of Nov. 16, 1973, Pub. L. No. 93-153, § 101, 87 Stat. 576 (amending Mineral Lands and Mining Act of $1920, \S 28,30$ U.S.C. $\S 185$ (1970)). Congress also declared that construction of the pipeline could begin without any further action under the National Environmental Policy Act. Trans-Alaska Pipeline Authorization Act, Pub. L. No. 93-153, 87 Stat. 584 (codified at 43 U.S.C. $\$ 1652$ (d) (Supp. III 1973)).

${ }^{109}$ Wilderness Soc'y v. Morton, 495 F.2d 1026, 1036 (D.C. Cir. 1974). Although the Department of the Interior and the State of Alaska were defendants along with the Alyeska Pipeline Service Co., only Alyeska was forced to bear the burden of the costs incurred by the environmentalists. The court felt that 28 U.S.C. $\$ 2412$ (1970) barred an assessment of fees against the United States, and that the circumstances of the case would make it unfair to assess any of the fees against the State of Alaska. Id. at 1036 \& n.8. Because the fees could not be spread among all the defendants, the court determined that Alyeska should pay only one half of the plaintiffs' attorneys' fees and that plaintiffs should absorb the other half. Id. at 1036.

110 "Acting as private attorneys general, not only have [plaintiffs] . . ensured the proper functioning of our system of government, but they have advanced and protected in a very concrete manner substantial public interests." Id. The court noted that prevailing in the litigation was not a prerequisite to an award given the rationale for the exception: "The advancement of important legislative policy justifying an award of attorneys' fees can be accomplished even where the plaintiff does not obtain the ultimate relief sought by the filing and prosecution of his suit." $I d$. at 1034 .

111421 U.S. at 245. See Mineral Lands and Mining Act of 1920, § 28, 30 U.S.C. $\S 185$ (1970); National Environmental Policy Act of 1969, 42 U.S.C. $\$ \S 4321-47$ (1970).

112 The court found the facts of the case did not justify an award under the bad faith exception: "Appellees' legal position as to the meaning of the Mineral Leasing Act and relevant administrative regulations, though ultimately rejected by the court, was manifestly reasonable and assumed in good faith, particularly in view of the long administrative practice supporting it." 495 F.2d at 1029 (citation omitted). The court did not specifically refer to the common fund exception; rather, it confined itself to analyzing the circumstances of the case in light of the broader "common benefit" theory. See note 114 infra \& accompanying text.

113 " '[T] his litigation may well have provided substantial benefits to particular individuals and, indeed, to every citizen's interest in the proper functioning of our system of government. But imposing attorneys' fees on Alyeska will not operate to spread the costs of litigation proportionately among these beneficiaries.' " 421 U.S. at 245 n.14 (quoting Wilderness Soc'y v. Morton, 495 F.2d 1026, 1029 (1974)). 
States-ostensibly the beneficiary of the environmental suit-to be an ascertainable class would "stretch [the exception] . . . totally outside its basic rationale.' "114 Furthermore, a private defendant is rarely in a position to distribute the costs of public interest litigation equitably to the public. ${ }^{115}$ Justification for the award, therefore, rested on judicial authority to shift fees solely upon a determination that an important congressional policy had been substantially advanced. Alyeska disavowed that a federal court's equity power included such unfettered discretion in the award of attorneys' fees and asserted that "legislative guidance [is necessary] to consider some statutes important and others unimportant and to allow attorneys' fees only in connection with the former."116

Equitable fee shifting, therefore, is strictly limited by Alyeska to cases falling within the traditional exceptions. Beyond these exceptions, authority for fee shifting in any case must be provided expressly by Congress. ${ }^{117}$

\section{Application of the Substantial Common Benefit Exception}

As an alternative approach to statutory fee shifting under a liberal interpretation of section $304(\mathrm{~d})$, courts could justify a fee award on facts similar to those in Georgetown as an exercise of equitable fee shifting power under the traditional substantial common benefit exception to the American rule. ${ }^{18}$ The district court found that plaintiffs' suit substantially benefitted the local community of the District by publicizing the negligence of the public officials in enforcing the Clean Air Act. Taxing the plaintiffs' attorneys' fees to municipal funds is arguably an equitable means of spreading the expense of the litigation to its beneficiaries-the citizens of the District. Thus, the three prerequis-

${ }^{114} I d$. at 245 (quoting Wilderness Soc'y v. Morton, 495 F.2d 1026, 1029 (1974)).

115 See id. at 264-67 n.39.

${ }_{116}$ Id. at 263-64.

${ }_{117}$ In response to the Alyeska decision, Congress amended the Civil Rights Act of 1866 to give the federal courts the power to award attorneys' fees to prevailing parties in suits brought to enforce civil rights acts. The Civil Rights Attorney's Fees Awards Act of 1976, Pub. L. No. 94-559, 90 Stat. 2641 (amending 42 U.S.C. $§ 1988$ (1970)). "The purpose of this amendment is to remedy anomalous gaps in our civil rights laws created by $[$ Alyeska], and to achieve consistency in our civil rights laws." S. REP. No. 1011, 94th Cong., 2d Sess. 1, reprinted in [1976] U.S. Code CoNG. \& AD. News 6338, 6339 (footnote omitted). This power is strictly limited to suits "arising under our civil rights laws, a category of cases in which attorneys fees have been traditionally regarded as appropriate." Id. 4. "This bill creates no startling new remedy-it only meets the technical requirements that the Supreme Court has laid down." Id. 6. Consequently, this legislation has no effect upon the judicial power to award attorneys' fees in environmental litigation. 
ites to an award of fees under the exception-definite benefit, discrete beneficiary class, and efficient fund-sharing mechanism-are satisfied. Furthermore, such an award would be within the limits placed on equitable fee shifting by the Supreme Court decisions in Fleischmann and Alyeska.

Before proceeding to the issues raised by Fleischmann and Alyeska, an initial inquiry should be made into the relevance of plaintiffs' defeat on the merits to the judicial power to shift fees under the substantial common benefit exception. The failure of the district court to consider the applicability of the exception undoubtedly stemmed from its view that the exception was only available to award fees to a successful party. ${ }^{119}$ The district court's view is supported by dicta in the Supreme Court opinions Mills and Hall. ${ }^{120}$ No persuasive reason exists, however, to construe the rationale of the exception as limited to prevailing parties. Georgetoun is an excellent example of unsuccessful litigants conferring significant benefits on a discrete class. The district court specifically noted the enormous problems of proof faced by the plaintiffs in Georgetoun. ${ }^{121}$ Despite plaintiffs' understandable inability to overcome these barriers of proof, the court nonetheless found that plaintiffs had rendered substantial service to public awareness. ${ }^{122}$ In effect the court may have been suggesting that the success of a suit in a broad sense is not necessarily limited to a favorable determination on the merits. ${ }^{123}$

${ }^{118}$ The obdurate behavior exception was inapplicable in Georgetoun because, although they were alleged to be neglectful regulators, the District officials were not charged with bad faith or unnecessary delay in the course of the litigation. Brief for Appellee at 25; Brief for Appellant at 43. Arguably the District was obdurate because it was dilatory in the implementation of indirect source review. Although awards have been made for obdurate behavior where compliance with a statute has been delayed unreasonably, these cases involved continued patterns of evasion and outright refusal to comply when the letter and spirit of the statute were clear. Awards in response to this type behavior have usually been predicated on a pattern of evasion of civil rights statutes over an extensive period of time. E.g., Bell v. School Bd., 321 F.2d 494, 500 (4th Cir. 1963); Cato v. Parham, 293 F. Supp. 1375, 1378 (E.D. Ark.), affd, 403 F.2d 12 (8th Cir. 1968). See note 89 supra \& accompanying text.

The common fund exception was inapposite to the Georgetoun facts because plaintiffs neither established a new fund nor protected an existing one. See notes 91-93 supra \& accompanying text.

119 See 383 F. Supp. at 143-44.

12" See Hall v. Cole, 412 U.S. 1, 5-9, 15 (1973); Mills v. Electric Auto-Lite Co., 396 U.S. 375, 392, 395-97 (1970). The Mills Court, however, refused to decide whether plaintiffs were entitled to an award of their attorneys fees on remand, see note 64 supra, regardless of whether they were successful in proving actual injury or obtained "significant relief." 396 U.S. at 390 n.13.

121383 F. Supp. at 145.

122 Id.

${ }^{123}$ The district court sought to justify its award as pursuant to section 304(d) au- 
Even assuming, however, that plaintiffs' defeat on the merits barred application of the substantial common benefit exception in Georgetown itself, courts may still wish to apply the doctrine in future cases similar in all respects except for the outcome. Of course, if plaintiffs are successful courts would also have authority to tax fees to the private defendants under section 304(d). The problem will be, however, that no award or only a partial award of fees against the private defendants will be appropriate if, as alleged in Georgetown, the public defendants are principally responsible for the litigation by reason of regulatory neglect. In prosecuting a successful action that ostensibly should never have been necessary but for the laxity of local regulators, plaintiffs will have conferred a benefit upon the local community. Therefore, taxing the public defendants joined to the suit under federal question jurisdiction will be appropriate. By assumption, however, the liberal interpretation of section 304(d) has been rejected as an alternative. Given this rejection, the courts in future cases may wish to apply the substantial common benefit exception to justify an award of fees to the successful plaintiffs assessed against the public defendants.

Fleischmann held that an intricate statutory remedial scheme may preempt what otherwise would be a legitimate judicial exercise of equitable fee shifting power. The same issue is present here in light of the express statutory provision in section 304(d) for fee awards in suits arising under the Act if the party to be assessed was joined pursuant to section 304(a). ${ }^{124}$ The statutory provision involved in Fleischmann, however, authorized recovery of damages, trebled in some instances. ${ }^{125}$ Because such a remedy

thority and not under the common benefit exception. See text accompanying note 40 supra. Although the court recognized that section 304(d) awards could be made irrespective of the outcome of a suit, see id., it exercised a presumption against such awards to unsuccessful parties. See 383 F. Supp. at 144-45. Thus, even in making its award under purported statutory authority, the district court felt a need to address, if only tangentially, the issue of plaintiff' lack of success.

${ }^{124}$ Relevant to this inquiry is section 304(a)'s limited scope reaching only polluters with the single exception that one regulator, the Administrator of the EPA, is covered if he has failed to perform a non-discretionary duty. 42 U.S.C. $\S 1857 \mathrm{~h}-2$ (a)(2) (1970). The Act also provides explicit remedies where local regulators fail to exercise their duties: (1) if the local regulators never submit an implementation plan or the plan submitted is inadequate, the Administrator is authorized to promulgate a plan for the locality, 42 U.S.C. $\$ 1857 c-5$ (c) (1970); (2) if the local regulators fail to enforce the requirements of an implementation plan, the Administrator is authorized to undertake enforcement measures in their stead, 42 U.S.C. $\$ \$ 1857 \mathrm{c}-8,1857 \mathrm{~h}-1$ (1970). The statutes involved in Mills and $H$ all, however, similarly establish complex federal regulatory schemes, and those cases nonetheless found Fleischmann distinguishable and made fee awards under the substantial common benefit exception.

${ }^{125}$ See note 104 supra \& accompanying text. 
substitutes in practice for compensation to the litigant for his counsel fees, the Fleischmann Court's determination that the additional remedy of an equitable award of attorneys' fees is preempted by the statute is not surprising. Damages are not available, however, in citizen suits to enforce the Clean Air Act. ${ }^{126}$ Fleischmann is, therefore, distinguishable on this ground; furthermore, in the subsequent Mills and Hall decisions, the Supreme Court distinguished Fleischmann. In these later decisions specific provision for counsel fee awards elsewhere in the statutes involved was held not to preempt equitable awards of fees under the general remedial provisions of the statute. ${ }^{127} \mathrm{Fi}$ nally, Fleischmann held that a "meticulously detailed" remedial provision would preempt equitable fee shifting, ${ }^{128}$ but the broad direction in section 304(d) for award of fees "whenever the court determines such award is appropriate" hardly meets that description.

Courts wishing to employ equitable fee shifting under the substantial common benefit exception in cases presenting facts similar to Georgetown will also have to distinguish Alyeska. Although the narrow holding in Alyeska removed judicial equitable fee shifting power only under the private attorney general theory, given the similarity of analysis under that theory and the common benefit rationale, ${ }^{129}$ the courts are likely to require careful delimitation of the latter approach. The critical issue is whether the Georgetoum case is analogous to the Mills and Hall cases in which application of the substantial common benefit exception was specifically approved in $A l y e s k a^{130}$ or whether the case is factually analogous to Alyeska itself.

Regarding the element of ascertainable benefit, the concern in Alyeska was that courts should not have the discretion to select statutory policies important enough to warrant counsel fee awards; that choice was to be for Congress. Notwithstanding this concern, the Court approved the awards in Mills and Hall even though the statutory provisions concerned contained no express authorization of fee shifting. Rather than view section 304(d) as preemptive of fee awards without its scope-an objection already

${ }^{126}$ See notes $24-25$ supra \& accompanying text.

${ }^{127}$ See Hall v. Cole, 412 U.S. 1, 10-11 (1973); Mills v. Electric Auto-Lite Co., 396 U.S. $375,390-91$ (1970).

${ }^{128} 386$ U.S. at 719 .

${ }^{129}$ Some commentators saw the private attorney general concept, at least under certain conditions, as the substantial benefit exception carried to its furthest extension. See King \& Plater, The Right to Counsel Fees in Public Interest Environmental Litigation, 41 Tenn. L. Rev. 27, 61-62 \& n.169 (1973); Comment, note 82 supra, at 667-68. 
addressed ${ }^{131}$ - the provision arguably indicates, if anything, congressional approval of citizen suits that should be encouraged by attorneys' fees awards under traditional equitable exceptions.

The elements of ascertainable beneficiary class and availability of an equitable fund-sharing mechanism are interrelated and will be treated together. The District of Columbia in Georgetown and a state in a future case ${ }^{132}$ arguably are ascertainable classes in the same manner as corporations and unions. Similarly, taxation of fees to District or state funds, like taxation of corporate or union funds, fairly spreads this expense to the members of those classes. Alyeska, however, strongly intimates that the general public of the United States, or any one state or the District of Columbia for that matter, is too large and diffuse to constitute an ascertainable class. ${ }^{133}$ Two distinguishing points should be made, however. The objection in Alyeska was directed more at the inequitable spreading of cost to the general public if fees were taxed to the private corporation, Alyeska Pipeline Service Co. The extent to which a rise in prices charged by a private corporation shifts costs proportionately to members of the general public cannot be gauged with any accuracy, except perhaps by "sophisticated economic analysis."134 Taxing public funds, in contrast, can effectuate fair distribution of costs to the public. Secondly, in Alyeska, the United States was by statute specifically immune to fee assessments. ${ }^{135}$ The Alyeska Court, however, left open the issue whether states' eleventh amendment immunity barred an award of attorneys' fees against state funds. ${ }^{136}$ Persuasive argument has been made that it should not. ${ }^{137}$ Significantly,

${ }^{130} 421$ U.S. at 258.

${ }^{131}$ See text accompanying notes $124-27$ supra.

132 The Clean Air Act, in accordance with concepts of federalism, is structured as a joint state-federal regulatory scheme. 42 U.S.C. $\$ 1857$ (1970). The District of Columbia is a "state" for purposes of this scheme. 42 U.S.C. $\$ 1857 \mathrm{~h}(\mathrm{~d})(1970)$.

133421 U.S. at 264 n. 39.

${ }^{134} \mathrm{Id}$.

${ }^{135} 421$ U.S. at 246,264 n.39, 265-68 \& nn. 40-42. Award of attorneys fees against the United States or any agency or official of the United States, unless specifically provided for by statute, is barred. 28 U.S.C. $\$ 2412$.

${ }^{136} 421$ U.S. at 269 n. 44.

${ }^{137}$ No eleventh amendment problem is presented by fee awards under the express provision of $\S 304(\mathrm{~d})$ against state polluters joined under $\S 304$ (a) jurisdiction. Congress expressly grants jurisdiction under this section over states "to the extent permitted by the Eleventh Amendment." 42 U.S.C. $\$ 1857 \mathrm{~h}-2$ (a)(I)(ii) (1970). Congress may, pursuant to its commerce power (and insofar as it is not limited by the tenth amendment), deprive a state of its eleventh amendment immunity to suit by one of its citizens if it does so by "clear language." Employees of the Dep't of Pub. Health \& Welfare v. Dep't of Pub. Health \& Welfare, 411 U.S. 279, 285 (1972). See generally Note, Attorneys' Fees ana the Eleventh Amendment, 88 HARV. L. REv. 1875, 1897-1901 (1975). 
the Court did not summarily dispose of the entire issue by holding that the residents of a state constitute too diffuse a class to

The eleventh amendment also presents no complete bar to the mere joining under federal question jurisdiction of state officials qua regulators to an action arising under section 304 brought by a state citizen where the action is for an injunctive remedy. See Ex parte Young, 209 U.S. 123 (1908); Note, supra at 1877-82.

The Supreme Court, wary of placing undue financial burdens on state treasuries with the consequent impairment of state sovereignty, has held, however, that the eleventh amendment limits the relief available in actions brought under the theory of Ex Parte Young to prospective as opposed to retroactive injunctive relief. Edelman v. Jordan, 415 U.S. 651 (1974). See generally Note, supra at 1879-82. Awards of attorneys' fees assessed against neglectful state regulators might therefore be prohibited under Edelman as constituting retroactive relief. Convincing argument, alluded to in the text, has been made for the proposition that awards of attorneys fees are valid under the eleventh amendment where, as arguably was the case in Georgetown, such awards are ancillary to lawsuits seeking only prospective injunctive relief. The courts of appeals have split on this proposition. Compare Souza v. Travisono, 512 F.2d 1137 (1st Cir. 1975) (upholding an award of attorneys' fees in a successful action to require state officials to permit access to legal advice for prisoners), vacated and remanded, 423 U.S. 809 (1975); Class v. Norton, 505 F.2d 123 (2d Cir. 1974) (upholding an award of counsels' fees and costs against a state official in a successful suit to compel compliance with federal welfare assistance regulations); Thonen v. Jenkins, 517 F.2d 3 (4th Cir. 1975) (affirming an award of attorneys' fees against defendant state university officials due to their obdurate behavior in a partially successful student civil rights suit); with Hallmark Clinic v. North Carolina Dep't of Human Resources, 519 F.2d 1315 (4th Cir. 1975) (affirming a denial of attorneys' fees as barred by the eleventh amendment in a successful suit enjoining state regulation limiting right to abortion); Skehan v. Board of Trustees of Bloomsburg State College, 501 F.2d 31 (3d Cir. 1974) (state college official immune by reason of eleventh amendment from attorneys' fee assessment in suit for due process violation in job termination), vacated on other grounds, 421 U.S. 983 (1975); Jordon v. Gilligan, 500 F.2d 701 (6th Cir. 1974) (vacating an award of attorneys' fees against a state in a successful challenge to a reapportionment plan), cert. denied, 421 U.S. 991 (1975).

Joining state regulators under federal question jurisdiction to section 304 citizen suits on the allegation that they have failed to fulfill duties imposed upon them by the Clean Air Act raises the broad issue of the extent to which Congress acting pursuant to any of its affirmative powers may require states to enforce federal law without impairing state sovereignty preserved by the tenth amendment. See National League of Cities v. Usery. 421 U.S. 833 (1976). A full development of this issue is beyond the scope of this Comment. One court of appeals has suggested that negative injunctions upon the states-for example, prohibiting the registration of vehicles not conforming with the applicable federal standards under the Clean Air Act-are consistent with tenth amendment state sovereignty, while affirmative injunctions upon the states-for example, requiring establishment of retrofit programs involving evaluation and approval by state officials of the devices to be used therein-impermissibly encroach on state sovereignty. District of Columbia v. Train, 521 F.2d 971, 988-95 (D.C. Cir. 1975), cert. granted, 426 U.S. 904 (1976). Presumably, states would be required to institute any necessary procedures ancillary to compliance with permissible negative injunctions. Thus plaintiffs in Georgetoum arguably were not barred by the tenth amendment from seeking a negative injunction against the District regulators prohibiting them from issuing construction permits to non-complying buildings, and an order requiring the regulators to institute pre-construction review as a necessary measure to compliance with the negative injunction sought would likewise be constitutionally permissible. Other circuits have divided on the general issue of the extent to which Congress may, pursuant to its commerce power, require states to enforce federal law. Compare Pennsylvania v. 
meet the ascertainable class prerequisite to attorneys' fees awards under the substantial benefit exception. ${ }^{138}$

Because Georgetoum arguably fits within the three criteria of the substantial common benefit exception as outlined in Mills and $\mathrm{Hall}$, the exception remains available to the courts for granting fee awards in future cases presenting strong justification. ${ }^{139}$

\section{ConClusion}

The demise of the private attorney general exception in Alyeska was a setback to public interest environmental litigation and put the onus on Congress to specify which statutes involve a public policy important enough to warrant fee shifting. The strict construction of the citizen suit provision by the District of Columbia Circuit in Citizens Association of Georgetown v. Washington is a further setback, in effect requiring Congress to carefully delineate all the situations under a particular legislative enactment that are appropriate for fee shifting. Such a construction burdens Congress with the formidable task of anticipating all the appropriate situations for fee shifting before the legislation has even gone into effect. Moreover, this construction ignores the practical reality that determining when fee shifting is warranted is often a minor consideration in the enactment of legislation as complex and controversial as the Clean Air Amendments.

The result in Georgetoun and the discouraging impact on environmental interest suits could have been avoided. A liberal interpretation of the express fee shifting provision of the citizen suit section of the Clean Air Act could have constituted a statutory basis for affirming the district court award of counsel fees to

EPA, 500 F.2d 246 (3d Cir. 1974) (federal government may constitutionally require a state to implement a traffic control plan under Clean Air Act) uith Brown v. EPA, 521 F.2d 827 (9th Cir. 1975) (Clean Air Act must be strictly interpreted to deny the Administrator enforcement powers against the states in order to avoid constitutional issues); cert. granted, 426 U.S. 904 (1976) and Maryland v. EPA, 530 F.2d 215 (4th Cir. 1975) (strict statutory interpretation denying Administrator power to direct state compliance with federal pollution regulations because of doubtful constitutional validity), cert. granted, 426 U.S. 904 (1976).

${ }_{138}$ See 421 U.S. at 266 n.39.

${ }^{139}$ The District of Columbia Circuit previously employed this doctrine in a post-Alyeska case to prevent "the perceived injustice of permitting third parties to benefit from the actions of another without sharing in the expenses incurred in securing or guaranteeing the benefit." National Treasury Employees Union v. Nixon, 521 F.2d $317,320,321$ (D.C. Cir. 1975): "Control over funds or assets is not a necessary condition for the application of this doctrine." 
plaintiffs. Alternatively, the award could have been justified as legitimate equitable fee shifting within the substantial common benefit exception to the American rule. Both Congress and the courts must reevaluate the practical and legal realities of this situation if they expect the private citizen to continue to play a part in the enforcement of environmental statutes. 